\title{
Messy genesis of the welfare state
}

\section{Paul Cairney examines the tangled history of one nation's drive for social equity.}

$\mathrm{T}$ he back cover of historian Chris Renwick's account of the British welfare state, Bread for All, offers an enticing statement for those interested in the role of science in social and policy change. That is, that this monumental programme was "linked by one overarching idea: that through rational and purposeful intervention, government can remake society".

That would indeed be an excellent lens through which to interpret Renwick's book. And a timely one: the idea of rational intervention is now much to the fore, as many scientists bemoan policymakers who favour 'irrational' approaches such as emotive conviction over scientific consensus. The current US administration, for instance, has no science-policy advisers and has turned its back on the science of climate change leading to the country's withdrawal from the United Nations Paris climate agreement.

Yet Bread for All does not provide an inspirational story of rational and purposeful intervention. It shows little of the 'comprehensive rationality' described by policy scholars, in which a government examines all data relevant to an issue before choosing policies guided by experts, then running them through processes of legitimization, implementation and evaluation. Instead, this is a history predicated on 'good enough' decisions, in which policymakers absorbed enough information to work with on the fly - a reflection of the 'bounded rationality' theorized by political scientist Herbert Simon.

Renwick's narrative is rich. Beginning with the Elizabethan Poor Law of 1601, he describes the centuries-long battle of ideas about how to address poverty. These hinged on how far governments should provide a 'safety net' and on whether doing so reduced incentives to work. By the early twentieth century, there was no resolution of this debate. Yet government policy (particularly during David Lloyd George's tenure as prime minister, from 1916 to 1922) was gravitating towards limited socialsecurity provision, targeting, for instance, people deemed too old to work. A phrase circulating then, 'homes fit for heroes', also suggested that First World War veterans should

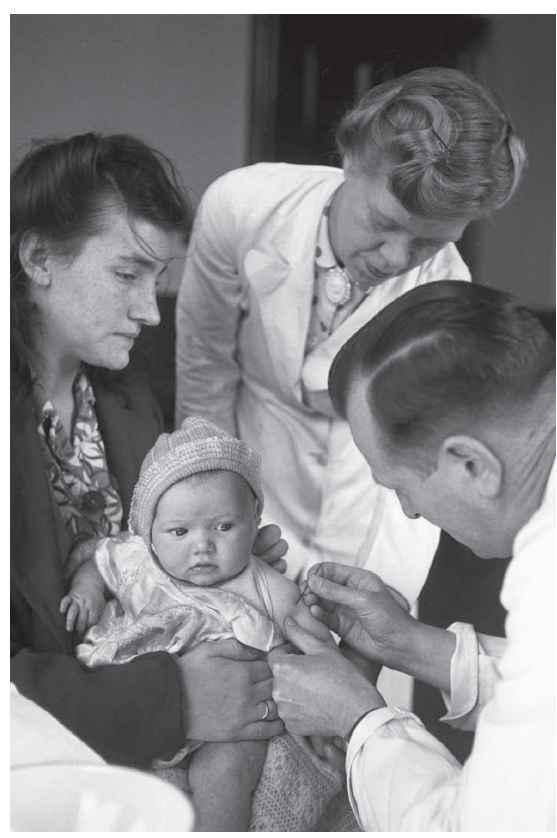

Many doctors were initially reluctant to work for the UK National Health Service.

be looked after. Decades later, as Renwick lays out, the culmination of all this was the extraordinary period of 1944-48, when a series of government acts and the establishment of the National Health Service ensured that everyone had access to housing, social security, health care, free education and more.

Throughout, dozens of potentially crucial thinkers emerge, along with the sense that no single one provided a winning argument. For instance, Liberal economist William Beveridge, author of the 1942 Beveridge Report, identified five "giant evils" in society, among them ignorance, poverty and disease. His work was pivotal in the establishment of the welfare state, yet Beveridge was often marginalized in or excluded from government.

As Renwick shows, the Second World War was crucial. The fulcrum for change was the need for a perceived contract between the British people engaged in the war effort and the government on whose behalf they fought. The war became a window of opportunity in which debates over welfare provision could be settled, and sustained political weight could overcome obstacles to major policy change. The intervention was thus purposeful, but not entirely rational. It reflects the 'multiple streams' analysis proposed by political scientist John Kingdon - in which attention suddenly lurches to a particular issue (how to reward millions of people after the war), a solution exists (an expanded welfare state) and policymakers are motivated (for instance, by unusually high support for change).

There is also a seat-of-the-pants element to the story - the first of three themes that jumped out for me in Bread for All. Renwick uses terms such as "maturing" to describe a concept of the welfare state that had evolved enough to drive policy, as if the outcome was inevitable when the idea's time had come. Yet he describes many ideas that came and went, among them now-discredited beliefs about eugenics in relation to social class. Nor was there cumulative progress in the lead-up to the 1940s miracle years. Instead, government support for key measures was sporadic, for instance when Lloyd George's government seemed too nervous about a media backlash to make major changes.

Second, expertise and evidence often had a remarkably peripheral role in decisions. During early-twentieth-century debates about a minimum wage or free school meals, governments before and after Lloyd George's decided to make major policy changes on the basis of a moral imperative, before gathering evidence on how to achieve the change or what the consequences might be. Each time, Renwick describes a government with little knowledge of economic realities, and policymakers who paid little attention to them.

Third, key aspects of policy delivery were achieved through persuasion and incentives, rather than rational intervention. That can be seen in how middle-class health visitors gained the trust of working-class mothers in the early 1900s, and how government bribed physicians in 1948 to ensure their cooperation in forming the National Health Service.

I find a story of high contingency in Bread for All. Not only did the welfare state emerge from a messy, unpredictable policy process, but it represented only one of many possible outcomes. Extrapolating from its lessons, I would say the following to scientists trying to influence comparable debates today. If you seek rational intervention, you will be disappointed; if you invest the time to skilfully exploit 'windows of opportunity' for policy change, you may get lucky.

Paul Cairney is professor of politics and public policy at the University of Stirling, UK. He wrote The Politics of Evidence Based Policy Making and runs a blog on the relationship between evidence and policy: paulcairney.wordpress.com. e-mail:p.a.cairney@stir.ac.uk 